\title{
138
}

Um certo sentimento do mundo

\section{Alcides Villaça}

Uma nova modalidade de discurso, associada a uma nova qualificação do tempo subjetivo e do tempo histórico, é uma característica essencial do livro Sentimento do mundo, de Carlos Drummond de Andrade. Para a sua análise, investiga-se a natureza de ritmos e imagens valorizados nos poemas, impulsionados pela força do "associacionismo" entre imagens e conceitos e pela dinâmica das figuras que valorizam a "porosidade" ou alternância dramática entre as forças gravitacionais da lírica pessoal e dos apelos coletivos.

A new modality of speech, associated with a new qualification of subjective time and historical time, is an essential characteristic of the book Sentimento do mundo, by Carlos Drummond de Andrade. In order to analyze it, the article proceeds to the investigation of the rhythms and images valued in the poems, driven by the force of the "associationism" between images and concepts and by the dynamics of figures that value the "porosity" or dramatic alternation between the gravitational forces of the personal lyricism and the collective appeals.

DOI 10.11606/issn.2447-8997.teresa.2020.156334 

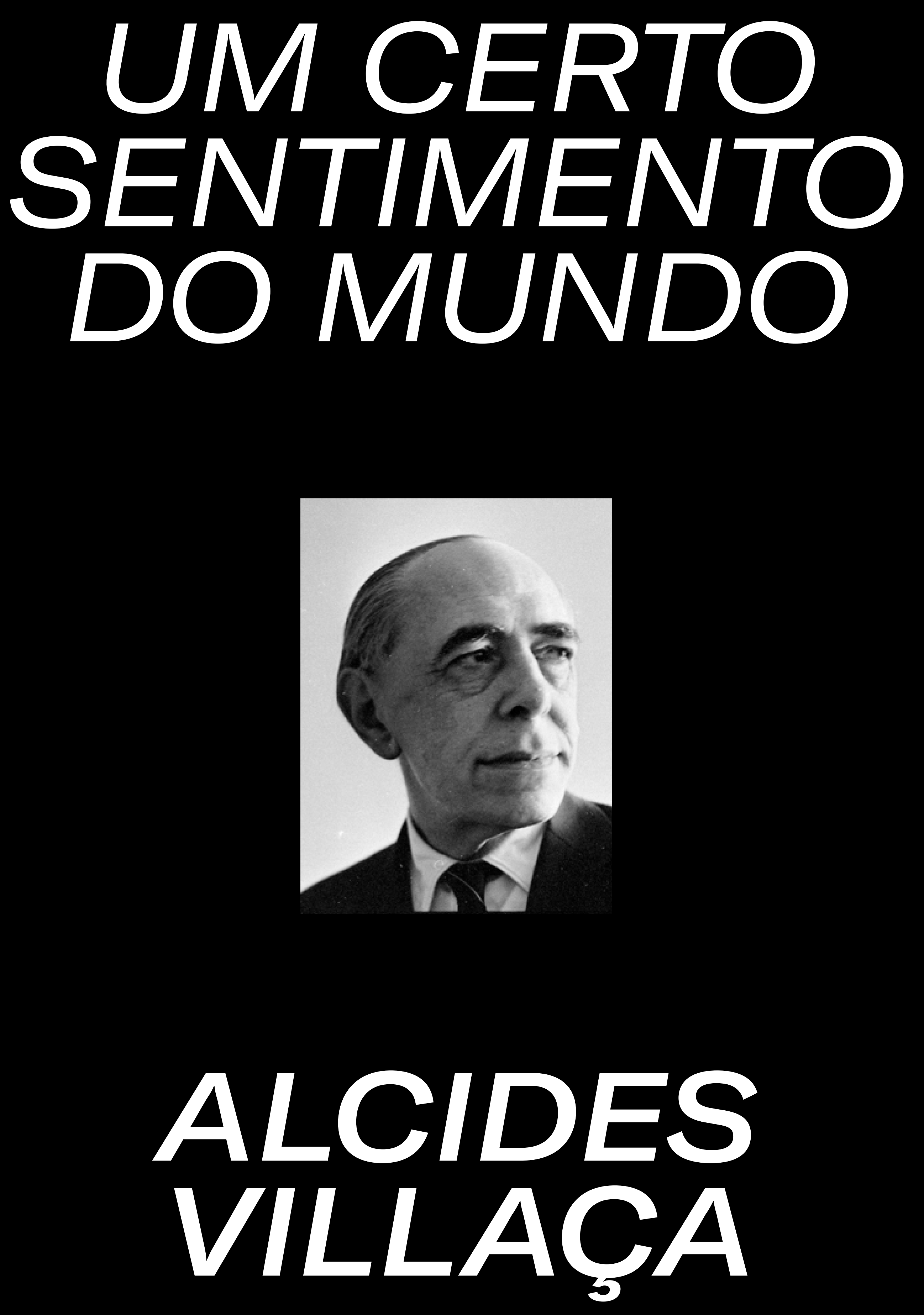
O conjunto de 28 poemas que Carlos Drummond de Andrade publicou, em tiragem reduzidíssima (150 exemplares), em 1940, recebeu o título de Sentimento do mundo - título em si mesmo surpreendente para o leitor que houvesse retido do livro anterior (Brejo das almas, 1934). A sensação de abafamento psicológico, de angústia no autocentramento, de insuficiência na comunicação, de mascaramento, de volúpia escatológica. Entre a dura contenção do poema "Segredo" e os catárticos "convites tristes", o poeta girava sempre na linha circular do personalismo, da timidez ou da vingança desta - linha também limite da linguagem dos poemas -, por vezes desferindo penosas exortações ao prazer e à morbidez. Que ocorre em Sentimento do mundo? E também: o que concorreu para o que se enuncia no título?

Batendo os olhos nos poemas do livro 1 já nos daremos conta dos versos mais longos, dos poemas mais desenvolvidos, dos períodos mais extensos, da prosa que invade os versos com um tom mais argumentativo, das muitas enumerações. Em uma palavra: é a discursividade que se impõe no predomínio de um ritmo e de uma sintaxe mais fluentes, do andamento de longas cadências lógicas e das imagens associadas em série. Essa maior fluência (que não exclui o recurso a versos e imagens mais sintéticos, ou mesmo a poemas apoiados em repetições, simetrias e alguma regularidade métrica) talvez deva ser o primeiro elemento estrutural a ser avaliado nessa nova configuração estilística - e não só estilística, evidentemente. A impressão que se tem é a de que o maior fôlego acompanha uma nova disposição de espírito, abertos ambos para o recolhimento e a expressão mais generosos da matéria poética - por sua vez mais alargada, complexa e historicizada que a matéria do livro anterior.

1 Para as citações dos poemas, valho-me da segunda edição de Obra completa. Rio de Janeiro: José Aguilar Editora, 1967. 
Tudo faz pensar numa nova qualificação do tempo, seja no plano da duração das unidades rítmicas e lógicas dos poemas, seja no plano existencial das sensações e atitudes do poeta, agora diretamente às voltas com a premência dos fatos e das experiências do mundo. Esses planos convergem solidariamente, e neles se promove essa nova qualificação, por via de um esforço de objetividade, reconhecível na mais intensa ligação entre as imagens e os conceitos, como entre a consciência e o desejo de ação do sujeito. "O tempo é a minha matéria, o tempo presente, os homens presentes, / a vida presente", diz o poeta em "Mãos dadas".

Não é possível deixar de considerar, já de saída, o tão sugestivo estudo de Otto Maria Carpeaux: "Fragmento sobre Carlos Drummond de Andrade", publicado em Origens e fins. Nesse estudo, o crítico - um intelectual austríaco refugiado, com muito pouco tempo de Brasil faz encontrar sua sensação de exilado com a perplexidade instigante do gauche brasileiro, que agora se aplica em investigar o "mundo grande", mundo em guerra que se impõe como um desafio objetivo a todas as consciências. Carpeaux considera sobretudo a "poesia objetiva" de Drummond, "seu verso profundamente realista", "poesia de precisão máxima”, a par de ser ainda a "expressão duma alma muito pessoal”. O crítico detectou logo essa nova e perturbadora vertente da arte drummondiana, e soube reconhecê-la na perspectiva dos livros anteriores, numa formulação lapidar, mostrando que houve

o transporte das notações sensíveis, descontínuas, características do impressionismo sentimental - frequentes ainda na primeira poesia de Drummond, desaparecendo desde então - para a esfera da significação mais precisa, onde cada palavra está carregada de sentido, de “meaning", num conjunto rigorosamente construído. ${ }^{2}$

Esse transporte é interpretado por Carpeaux como a passagem do processo "associacionista" para o processo das "Gestalten", "estruturas nas quais cada parte tem o seu sentido definido só dentro da hierarquia do conjunto”. Essa leitura de Carpeaux é útil tanto para uma apreciação retrospectiva da poesia drummondiana quanto para o reconhecimento e a valorização de Sentimento do mundo.

2 Carpeaux, Otto Maria. Origens e fins. Rio de Janeiro: Casa do Estudante do Brasil, 1943, p. 333. 
Parecem afastados de vez, no livro de 1940, a captação mais fragmentária e irônica, que dominava Alguma poesia, e o fechamento do sujeito e da linguagem no registro mais monocórdico e melancólico, que marcava Brejo das almas. A construção mais rigorosa de conceitos, aliada a uma sensibilidade que busca evitar os álibis e as sublimações, indica que o poeta toma agora como desafio uma conjugação mais equilibrada entre o mundo íntimo e o mundo exterior - conjugação não propriamente harmônica, mas capaz de expor com maior nitidez os limites do sujeito e os do mundo. Ganhando força o mundo como problema, o gauchismo perde bastante de sua graça, e já não atua como elemento de tácita cumplicidade entre o poeta e o leitor. Desfazem-se as ironias mais contundentes, o piadismo mais imediato e a "solução" do sarcasmo, dando lugar ao tempo íntimo da observação ponderada, das cogitações e das resoluções - tempo que o poeta busca oferecer de si para o mundo, tanto quanto recolhe deste a força do presente, materializado seja na circunstância investigada do cotidiano, seja na avaliação mais ampla do momento histórico. Objetiva-se, desta forma, a natureza íntima - que tem diante de si o tempo aberto e já habitável da "vida sem mistificação" -, assim como se objetiva o mundo na consciência ética que o qualifica identificando-lhe as dores e as contradições.

Convém insistir: trata-se da poesia objetiva "duma alma muito pessoal"; trata-se de uma poesia que quer integrar conhecimentos e imagens num mesmo plano expressivo; trata-se, enfim, de uma poesia em que o peso do "sentimento" e o do "mundo" não caracterizam um impasse, mas uma relação problemática vivida em cada poema, a cada momento encenando um aspecto visível das contradições entre o indivíduo e a sociedade. Carpeaux lembra ainda que um estudo estilístico do livro encontraria nele duas séries de símbolos: "símbolos da individualidade" e "símbolos da coletividade". Entre estes últimos, estariam os "grandes Edifícios, caixões de cimento armado", as "grandes Cidades, cristais sujos da época”, e as "Instituições, sem adjetivo"; e entre os primeiros encontraríamos os signos da memória pessoal, os traços da solidão profunda, o coração que "também pode crescer". Lembremos nós, agora, que essas séries de símbolos surgem no centro de um discurso argumentativo, expressando os pontos extremos do difícil equilíbrio de duas verdades que se tensionam. A impossibilidade da conjugação parece advir ora de um lado, ora do outro; por vezes, o que se quer garantir é a sobrevivência do indivíduo "triste, orgulhoso, de ferro"; em outras, precisa-se reconhecer que "é grande o mundo", e que "ilhas 
perdem o homem". A saída seria o compromisso de tornar a "noite", que "dissolve os homens", em "aurora", que tinge o mundo com "as tintas da antemanhã". Tímido sujeito, tímida aurora: quase sempre os símbolos se cruzam, realisticamente, no plano instável da expectativa ou do puro desejo, cada custosa imagem buscando amparar a reflexão rigorosa.

Não se diga, pois, que em Sentimento do mundo estejam superadas ou abolidas as qualidades centrais do indivíduo lírico dos livros anteriores: persistem as restrições da timidez, a sensação de impotência, o coração tristemente orgulhoso de si. A novidade está no efetivo confronto dessas qualidades com as da realidade histórica que emerge e apresenta ao poeta a face trágica e provocadora. Permeáveis um para o outro, haverá entre o eu e o mundo formas de comunicação, que se apresentam na condição de símbolos. Entre estes, quero destacar as figuras que remetem às idéias de fluxo, de fluidez, de porosidade - instâncias do que é dinâmico e expansivo, do que encontra no elemento líquido sua melhor e mais natural representação. Vejam-se alguns casos (todos os grifos são nossos):

a. em "Operário no mar", a distância que parece conservar "irremediavelmente separados" o poeta e o operário por um momento se relativiza: "Único e precário agente de ligação entre nós, seu sorriso cada vez mais frio atravessa grandes massas líquidas, choca-se contra as formações salinas, as fortalezas da costa, as medusas, atravessa tudo e vem beijar-me o rosto, trazer-me uma esperança de compreensão";

b. em "Menino chorando na noite", a ponte sensível entre o eu e a criança sofrendo se faz com o rumor da "gota de remédio caindo na colher", com o "fio oleoso que escorre pelo queixo do menino,/ que escorre pela rua, escorre pela cidade";

c. em "Privilégio no mar", contra a ironia do mundo "sólido", de "cimento armado", o poeta cogita que "as águas tranquilas" da baía estariam comprometidas "houvesse um cruzador louco" nelas, a tornar a vida "incerta", "improvável";

d. em "A noite dissolve os homens", o advento revolucionário da "aurora" conclui-se com a seguinte passagem: "O suor é um óleo suave, as mãos dos sobreviventes se enlaçam,/ os corpos hirtos adquirem uma fluidez,/ uma inocência, um perdão simples e macio... [...]/ O mundo/ se tinge com as tintas da antemanhã/ e o sangue que escorre é doce, de tão necessário/ para colorir tuas pálidas faces, aurora”; 
e. em "Mundo grande", a metamorfose da consciência está nestas imagens: "Escuta a água nos vidros,/ tão calma. Não anuncia nada./ Entretanto escorre nas mãos,/ tão calma! vai inundando tudo...”;

f. em "Madrigal lúgubre", a imagem da alienação personificada na "princesa" de "mãos níveas" é contrastada em versos como "Sutil flui o sangue nas escadarias" e "em vossa casa, de onde o sangue escorre";

g. em "Noturno à janela do apartamento", à imagem primeira do "mundo enorme e parado" contrapõe-se a dinâmica da vida, que "tem tal poder:/ na escuridão absoluta,/ como líquido, circula".

Não será ilegítimo associar-se esse topos da fluidez à espécie mais cursiva da fala drummondiana deste livro, ao discurso que se expande com fluência na busca de comunicação com o outro: com o operário, com o menino na noite, com os companheiros, com os homens na rua. Versos mais fluentes, realidade mais penetrável, permeabilidade que torna a esperança possível - embora os obstáculos sejam muito poderosos, concentrando o poder do que é sólido, estático, sedimentado - o outro topos desse imaginário dialético, que assume as formas do orgulho "de ferro" ("alheamento do que na vida é porosidade e comunicação"), do "edifício sólido", do "coração que está seco", da "ilha", da noite que "paralisa os guerreiros", do "mundo caduco", mundo "enorme e parado". Topos que, já em Alguma poesia (e com garantida permanência na poética de Drummond), apresentava-se na fundamental imagem da pedra que obsta o caminho e se fixa para sempre nas "retinas fatigadas". Lugar da luta entre esses dois campos de imagens, o discurso drummondiano representa-se como sofrida dialética entre as negativas raízes do ser e a responsabilização dele diante do presente e do futuro do mundo - grande signo do tempo histórico e da concretude da vida. Tal dialética se faz representar, ainda, na oposição entre outros campos de imagens, como os da noite e os da luz. John Gledson já assinalou a força da primeira, força estruturante e simbólica da alienação ameaçadora; ${ }^{3}$ podemos confrontá-la, no entanto, com suas correspondentes antíteses. Em "Revelação do subúrbio", "pela manhã repontam laranjais” é a reação do campo à noite devoradora; em "A noite dissolve os homens", o signo "aurora" abre a parte final do poema e desenvolve-se como símbolo revolucionário; em "Os ombros suportam o mundo", contra a luz apagada

3 Cf. capítulo IV de Poesia e poética de Carlos Drummond de Andrade. São Paulo: Duas Cidades, 1981. 
"os olhos resplandecem enormes". "Lembrança do mundo antigo" é todo ele memória luminosa das manhãs, de "Clara", das cores vivas do tempo passado, trazido para oposição ao presente; em "Elegia 1938", o duro sentimento de derrota convive com o "terrível despertar", que repõe os problemas fora do alívio do sono.

Reconhecida a tensão que domina Sentimento do mundo, expressa nos vários temas, nas várias imagens em luta, impõem-se ao leitorintérprete questões fundamentais: essa tensão exprime forças em equilíbrio? Há proporção no jogo das imagens em conflito? Resulta de tudo, enfim, a impressão de dilemas que de fato dividem o poeta?

A resposta a essas questões não depende, é óbvio, da sinceridade que creditemos ou não ao poeta, às informações que ele dá quanto ao que dentro dele luta, mas da avaliação que faz nossa sensibilidade da força poética dessas imagens, devidamente compreendidas em seu contexto. A compreensão política do conceito de esperança, por exemplo, leva em conta correlações de forças históricas, enquanto que as imagens que lhe correspondem não têm por que evitar o plano do desejo, do mítico, do visionário. Tudo está em bem avaliar o plano de base em que o poeta situa seus poemas, o contexto geral em que se desencadeiam as imagens, o padrão de referencialidade e transfiguração que o discurso supõe em sua complexidade. Predomina em Sentimento do mundo o desejo real que tem o poeta de sair de si mesmo, de sua impotência individual; desejo de vencer o "mundo caduco" em que trabalha "sem alegria”. Ocorre que, em seu inarredável compromisso com a lucidez, o poeta não abdica do senso de realidade, e acusa logo a desproporção da tarefa: "Tenho apenas duas mãos/ e o sentimento do mundo". Vale dizer: sua poesia de agora nasce do esforço ingente de superação dos limites pessoais, não se admitindo, no entanto, desconsiderar esses mesmos limites. Para o sujeito, trata-se de enfrentar sua própria índole negativista, criando para si as imagens da solidariedade e da abertura para o mundo - as pedras de toque do livro. Dado que o leitor dos volumes anteriores nunca duvidou da força do gauchismo e da angústia, das ironias e sarcasmos desse sujeito, impõe-se-lhe agora a tarefa de avaliar o rendimento poético das imagens de positividade e esperança no Sentimento do mundo.

Pode-se dizer que, tomadas em si mesmas, as imagens mais combativas e afirmativas do livro não teriam como concorrer com a persuasão natural que provém das origens circunspectas do sujeito, preso à lúcida 
negatividade. A força do "anjo torto" é, do ponto de vista expressivo, atávica e determinante, constituindo a tese da luta dialética. Contra o imaginário do noturno, do sombrio, do paralisado, do ensimesmamento angustiado, as "auroras" e as "manhãs" convocadas podem surgir, de fato, como aparições artificiosas: afinal, trata-se da luta do desejo contra o peso do real, do conceito contra o que é imediato, da visão ardente contra a experiência já vivida e sedimentada. Trata-se de opor à noite, "que dissolve os homens" e que está associada ao indiscutível ônus do "mundo fascista”, a aspiração da carne que "estremece na certeza" do advento da "aurora", o voto de fé em que "havemos de amanhecer". Nessa oposição simples, a imagem da aurora tem algo de Deus ex machina convocado para abrir os impasses. Pareceme, no entanto, que o livro pode ser lido em outra chave que não seja a do embate simplificado entre o não e o sim; para isto, será preciso nuançar as posições e distinguir, entre os polos, sugestões mais poderosas que graduam os conflitos do poeta e particularizam os momentos do combate íntimo. Impõe-se o exame mais detido desse processo no poema.

\section{O “MENINO CHORANDO NA NOITE" E OS SÍMBOLOS DA POROSIDADE}

O poema "Menino chorando na noite" (de que tanto se agradou Mário de Andrade) encarna, a meu ver, um momento muito rico do livro, momento em que se efetua a passagem do motivo mais lírico, mais individual e mais melancólico para a significação ampla que o promove "no mundo".

\section{Menino chorando na noite}

Na noite lenta e morna, morta noite sem ruído, um menino chora O choro atrás da parede, a luz atrás da vidraça perdem-se na sombra dos passos abafados, das vozes extenuadas E no entanto se ouve até o rumor da gota de remédio caindo na colher.

Um menino chora na noite, atrás da parede, atrás da rua, longe um menino chora, em outra cidade talvez, talvez em outro mundo.

E vejo a mão que levanta a colher, enquanto a outra sustenta a cabeça e vejo o fio oleoso que escorre pelo queixo do menino, escorre pela rua, escorre pela cidade (um fio apenas).

E não há ninguém mais no mundo a não ser esse menino chorando. 
As expressões adverbiais do início - "Na noite lenta e morna", "morta noite sem ruído" - alongam a sensação do poeta dentro do arrastar do tempo noturno, do abafamento, do silêncio que tornam esse tempo como que corpóreo em seu peso. A repetição de "noite" alia-se à matéria fônica das repetidas nasais ("na noite lenta e morna, morta noite sem ruído"), produzindo uma cadeia de veladas assonâncias, imitativas da densidade do silêncio. $\mathrm{O}$ andamento das expressões adverbiais distribuise em dois compassos, igualmente miméticos da lentidão. De "morna" a "morta" adensa-se e unifica-se o peso do silêncio, cuja sensação tornará mais contrastada a ação "um menino chora", reservada para o final do verso. A extensa preparação adverbial situou o leitor, preliminarmente, no modo pelo qual a qualidade mesma do tempo se fazia perceber, para que só depois emergisse dele a informação principal, o choro do menino, que a um tempo desmente e ratifica o peso do silêncio na noite. Mais surda que tudo é a presença do poeta, olhos e ouvidos que recolhem uma dupla melancolia: a da noite pesada e a da queixa da criança. Esta sai daquela como num soturno desentranhamento, sugerindo o conjunto uma ampla tristeza geral: da noturnidade, da criança e do poeta (a quem a leitura poderá talvez imaginar a uma janela, igualmente engastado no cenário sombrio e pesado). Nos dois versos seguintes, o discurso é igualmente segmentado e compassado: "O choro atrás da parede" compõe a primeira célula rítmica; "a luz atrás da vidraça”, a segunda; "perdem-se na sombra dos passos abafados", a terceira; "das vozes extenuadas" a quarta e última. A inflexão das duas primeiras sugere uma curva de melodia ascensional, enquanto a das duas últimas opera em sentido inverso. O duplo movimento rítmico-melódico salienta, em primeiro lugar, a ação singularizada do choro e da luz - elementos que em princípio desmentiriam o silêncio e a escuridão; mas sentimos que ambos continuam a integrar a atmosfera geral, pelo que há de velado em "atrás da parede" e "atrás da vidraça”, em "sombra dos passos abafados" e em "vozes extenuadas". Vale dizer: a morfologia desses versos vem em apoio da oscilação entre a autonomia e a dependência dos termos principais: choro, luz, passos, vozes - imagens do que em princípio se destacaria do quadro, da estaticidade geral, mas que a ele se subordina por um processo de mediações em que tudo é atenuado, ensurdecido, ocultado: "atrás", "atrás”, "perdem-se”. Os agentes dessa cena noturna (o menino, os que cuidam dele, o poeta-observador) estão todos envolvidos pela qualificação maior da Noite - já uma onipresença 
determinante, a cada verso mais emblemática. Veja-se, pois, que o recorte de uma cena virtualmente prosaica, até banal, se deu em meio a tão carregado clima expressivo que a este se une de vez, o que é um modo de sugerir que a formulação lírica está presidindo a tudo, chegando-nos esse corte da realidade pelo mais impressivo filtro do poeta. A presença deste se insinua no último verso da estrofe, disfarçada na forma de indeterminação do sujeito: "se ouve". O que se ouve (o inaudível "rumor de gota”) atravessa, qual nítido filamento sonoro, a massa do silêncio; "rumor que, mais forte que tudo, atravessa parede e vidraça, distingue-se melhor mesmo que os passos e as vozes: o detalhe se amplia na atenção já imaginativa do poeta, aguçada e aberta para a cena. A expressão "e no entanto" adverte, sim, para a percepção impossível (ouvir uma gota, à distância) que se faz, porém, verdade subjetiva, signo da aproximação intensa do observador, que promove o pormenor em big close à significação ampliada e dramática.

A esse big close se oporá o movimento de um vertiginoso travelling à ré, na segunda estrofe: interpõem-se sucessivas mediações entre o menino e o observador: "atrás da parede", “atrás da rua”, "longe”, "em outra cidade", "em outro mundo". Em sucessivos cortes, ampliamse os planos, perdendo-se já a visão física da cena e impondo-se, vertiginosamente, espaços de pura alusão: estamos agora no interior da sensação do poeta, rumo à qual o movimento desse choro atravessou as circunstâncias e propagou-se como um signo de desconsolação do "mundo". As sucessivas dimensões de "atrás", "atrás", "outra cidade", "outro mundo" já não apreendem a cena e seus detalhes materiais, mas projetam seu conteúdo para fora deles, síntese de uma melancolia geral que se casa com o clima do início do poema, daquela "noite lenta e morna, morta noite sem ruído". A repetição de "talvez" dá conta, por outro lado, do impulso subjetivo dessa síntese, afirmando a presença emocional do observador e do particular sentimento que nesse instante o invade. Da cena a princípio doméstica, em que se recortou exatamente o que era detalhe e percepção material, desdobra-se o que ela continha de mais sugestivo: uma insinuante dimensão cósmica.

Na última estrofe, processa-se uma veloz reaproximação do sujeito em direção à cena, desta vez assumindo-se a primeira pessoa: “vejo a mão que levanta a colher" e "[vejo] o fio oleoso que escorre pelo queixo do menino". Por trás da vidraça iluminada (qual um fotograma aceso na noite), o gesto de quem administra o remédio é cuidadosamente descrito 
("levanta a colher", "sustenta a cabeça"); mas, dentro do mesmo "vejo" há também o "fio oleoso que escorre pelo queixo do menino,/ escorre pela rua, pela cidade (um fio apenas)" - conjugação do visível e do invisível, do real e do metafórico, do sentimento vivo e dos sentidos hipertrofiados. De novo uma hipérbole se fez necessária para a união entre e mundano e o cósmico, construindo-se pelo fluídico "escorre" a permeabilidade dos planos. Há, aqui, a comunicação mais intensa do particular e do geral, mediada no interior do poeta - ele próprio permeável à "dor individual" e ao "sentimento do mundo". Aqui, o sujeito se esquece dos conselhos desencantados de "Segredo" (Brejo das Almas) - "Fique torto no seu canto", "Não ame”, "Não diga nada” etc. - e parece apostar em que a poesia é comunicável (ainda que restrita a essa dimensão lírica do noturno e do silêncio), em que o corpo é sensível aos choros deste mundo, e que é possível a mais patética solidariedade com a dor do outro (dor que "vemos", mas que também "escorre" invisível pelo mundo).

O verso final processa, em aparente paradoxo, uma grande restrição e um grande alargamento do sentido. A restrição ("não há ninguém mais no mundo a não ser") carrega toda a sua força na operação de um esvaziamento geral, de que resulta enfim a particularíssima imagem desse "menino chorando", sobre quem repousa em definitivo o olhar do poeta. Ocorre que esse olhar (já o notamos nós) construiu também a sugestão de dor universal que habitou o sujeito, que estendeu a melancolia da cena às ruas e às cidades do mundo. Criou, com isso, uma ligação definitiva, impossível de se apagar, entre o menino e a ampla noite "lenta e morna", que parece recolher o Tempo, a Natureza, a Humanidade, o Destino, no seio da expressão negativa. Por via dessa ligação, não há como singularizar até o fim o choro do menino: é preciso entendê-lo no sentido em que o poema todo se empenhou, no sentido de um lamento que já não pertence apenas à criança ou ao poeta - seus atores e sua circunstância -, mas à condição essencial do mundo apresentado como um grande "menino chorando", tornado assim visível e sensível para nós. "Um fio apenas", diz o poeta, "escorre pela rua, pela cidade": fio suficiente, no entanto, para dotar de matéria a permeabilidade universal, em que já não se distingue o sujeito e o observador da melancolia, transfundidos no "fio oleoso" que escorre por toda parte e que denuncia, na viscosidade, o elemento solidário que nos faz ver o menino e o mundo, ambos chorando na "noite lenta e morna" do tempo presente. $\mathrm{O}$ mundo é um menino doente. 


\section{LIMITES E EXPANSÕES DO LIRISMO}

Em outros poemas do livro surpreenderemos momentos que, como o de "Menino chorando na noite", promovem a imagem mais particular ao plano de uma expressão universal, em que aquela se amplia e transborda de si mesma. Em "Os mortos de sobrecasaca", o verme que roeu o "álbum de fotografias intoleráveis" roeu a tudo, mas não roeu "o imortal silêncio de vida que rebentava/ que rebentava daquelas páginas"; em "Confidência do itabirano", todas as memórias do poeta parecem conter-se, diminuir-se e paralisar-se em "apenas uma fotografia na parede", mas o verso final - "Mas como dói!" - dá conta da dor agônica que atualiza a consciência do tempo e coloca o "funcionário público" numa dimensão trágica, que se opõe à rotina e se tempera de lucidez; em "Ode ao cinquentenário do poeta brasileiro", a maior virtude que Drummond homenageia em Manuel Bandeira e á que torna "seu canto confidencial" o "consolo de muitos e a esperança de todos"; em "Mãos dadas", a abstração do tempo ("mundo caduco" ou "mundo futuro") é combatida pela "matéria" em que o tempo deve se converter ("tempo presente", "homens presentes", "vida presente"); em "A noite dissolve os homens", a "noite desceu", a "noite anoiteceu tudo", mas dentro dela o poeta convoca a "aurora" em "seu sangue que escorre", sangue "necessário" para aquele que conta que "havemos de amanhecer"; em "Mundo grande", depois de considerar quão diminuto é o "peito do homem", quanto é "triste ignorar certas coisas" e como é fácil habitar "países imaginários" e "ilhas sem problemas", o coração "cresce dez metros e explode", explosão também do grito final do poema: "Ó vida futura! nós te criaremos".

Ao lado de poemas em que ocorre este nítido movimento para o mundo, há os que falam da falta desse movimento, e correspondem à feição do individualismo que Drummond tantas vezes exacerba, como para punir em si mesmo sua tendência mais negativista. Tudo está em que compreendamos que a concorrência desses dois planos poéticos em Sentimento do mundo acaba por realizar entre eles o movimento que em cada um deles já é tratado como tema. Veja-se, por exemplo, que a contiguidade entre "Mundo grande" e "Noturno à janela do apartamento" - os dois poemas que encerram o volume - é bastante sugestiva: a exaltação esperançosa do primeiro dialoga com a dura melancolia do segundo, constituindo ambos um movimento dramático em que "o fogo e o amor", que qualificam o dinamismo do "mundo grande", são contestados pela conclusão amarga de que "a soma da vida é nula”, conclusão de quem está “à janela do apartamento”. Como não se pedirá à poesia a coerência tantas vezes abstrata das ideologias, o leitor 
de Drummond não perderá o sentido maior de uma dialética em que o peso do real (dado da memória, circunstância presente, fato experimentado, limite consciente) é posto em dinâmica pela força das expectativas estas, inevitáveis no tempo histórico do período coberto pelos poemas de Sentimento do mundo. Trata-se, enfim, de manter-se o sujeito mais do que nunca fiel às suas tendências contraditórias, ambas presas a verdades: a verdade da condição concreta do sujeito tímido e gauche, lúcido quanto aos limites que lhe impõem o personalismo e as tantas "impossibilidades"; e a verdade do mundo, mundo cheio de signos e apelos que provam, a esse mesmo sujeito, que a condição da timidez não deixa de dotá-lo de capacidade de observação rigorosa e agudo interesse pelos fatos, dentro dos quais o individualismo se obriga à adesão afetiva, emocionada - e por que não à política? Esta última ocorre, assim, não como entrega calculada a programas e ideias, mas como necessidade de expansão da poesia e da consciência num poeta cujos versos não têm (ou não querem mais ter) álibis de inocência; versos que buscam, nos lugares problemáticos, ganhar terreno ao silêncio, à incomunicabilidade, à "noite" simbólica da "nulidade da vida”. Não por acaso, o Carpeaux crítico e refugiado político viu no poeta um tradutor "objetivo" dos dilemas "presentes": "Quero dizê-lo, com toda a franqueza, que o encontro com a poesia de Carlos Drummond de Andrade me foi um conforto nas trevas, e que eu, que conhecia todas as poesias do mundo e experimentava todas as desgraças do mundo, compreendo melhor agora o sentido de uma longa viagem". ${ }^{4}$ Para não ficar no ar qualquer injustiça diante do suposto pieguismo que, da parte do crítico, tivesse se espelhado em algum do poeta, lembremos ainda que Carpeaux não admite jamais o "elogio subjetivo", nem a atração simplória pelos bons sentimentos que nunca garantiram a força da expressão artística; ele tem a convicção de que a arte é dialética e se faz nos movimentos contraditórios, próprios à expressão da realidade mais concreta - igualmente contraditória. Digamos, enfim, que as declarações ideológicas de alguns versos de Sentimento do mundo, por certo poeticamente menos felizes em si mesmas, devem ser confrontadas com as imagens da escavação e da procura subjetivas, no movimento que vimos interpretando. É esse mesmo movimento que dá ao livro e à poesia de Drummond um fôlego capaz de gerar, nos anos seguintes, tantos poemas fundamentais de $A$ rosa do povo (1945), constituindo, ambos os livros, um momento poderoso da poesia do século XX.

4 CARPEaux, Otto Maria. Origens e fins. Op. cit., pp. 337-338. 


\section{UM PROCESSO, DUAS VERDADES}

Parece ser das convicções drummondianas a ideia de que a autodeterminação supõe agora, mais do que nunca, um processo. Mais humilde, o poeta como que reavalia sua condição, fazendo-lhe uma correção na melancolia do gauche para, mais materialmente, determinar-se enquanto cidadão de seu país e do mundo. Relativiza, ainda, a dimensão psicológica, para encarecer a condição de um novo habitante da cidade, nas tantas referências (ao Leblon, ao Méier, ao Pão de Açúcar, a Copacabana, ao morro da Babilônia, ao Mangue, à Lapa, à Ilha Rasa) de uma geografia próxima e familiar. Em "Confidência do itabirano" a consciência desse processo revisional está firmada no reconhecimento do novo status, entre irônico e realista, de "funcionário público" que, na metrópole moderna, não conserva de sua cidade natal mais do que uma "fotografia na parede". O passado dói, enquanto lembrança irremissível, e marcou para sempre o itabirano "triste, orgulhoso: de ferro", alheado "do que na vida é porosidade e comunicação", com "vontade de amar" e o "hábito de sofrer". Essas qualidades surgem agora sob a forma de "prendas", num hábil movimento de preservação e doação, paradoxo que se estampa todo na expressão "este orgulho, esta cabeça baixa”. Nos últimos versos, o saldo parece definitivo: do ouro, do gado, das fazendas dos ancestrais o poeta nada conserva, senão o "como dói” nostálgico no burocrata pedestre e desambicioso. Todo o passado, simbolicamente concentrado na fotografia de Itabira, resta estático diante do "Hoje sou funcionário público", condição presente e decisiva. Belo Horizonte surge emblematicamente associado à "Moça-Fantasma”, a viagem para Minas é feita contemplativamente "de pé, contra a vidraça do carro,/ vendo o subúrbio passar", o mundo tornou-se "caduco", "enorme e parado" - fantasmagorias de um passado recente que já é, no entanto, o "do mundo antigo": antes de 1939. O ano da guerra abre uma ampla elegia, que ainda assim abriga a contestação: o funcionário trabalha sem alegria, mas parece estar agora liberto dos anjos, das sonatas, das confissões patéticas de outrora, como em "Mundo grande" - poema no qual as fantasmagorias cedem lugar à iniciativa pela "vida futura": "nós te criaremos". Esse ambíguo estatuto de melancolia atávica e disposição participativa faz de Sentimento do mundo um livro repuxado, oscilante na determinação ora de uma, ora de outra.

Ponte possível para a ação é o sentimento do mundo: no interior da sensibilidade e da linguagem arma-se a vontade de se fugir das ilhas que "perdem os homens" e a decisão de estender o discurso aos limites da autopersuasão. Fluídico, o mundo combate a esterilidade dentro do 
sujeito, agora mais poroso e loquaz; mas não é sem resistência que os apelos da contemporaneidade tomam de assalto as reservas da consciência irônica e ressentida em que subsiste algo do brejo das almas. Na fortaleza desolada dos limites íntimos, da timidez e do humour, será preciso vencer o "coração orgulhoso". Explodi-lo talvez seja uma solução, mas não permanecerá intacta a ponte de Manhattan? A mobilização mais positiva dos afetos terá alguma contrapartida na ordem do mundo? O sacrifício da negatividade pessoal que é, de qualquer modo, a marca do sujeito, tornará a vida mais justa e confiável? Drummond tende aqui a um sim fundamental, mas a cada passo encontra em si mesmo as reticências que a retórica mais convicta está longe de vencer. O "problema da opção" fazse representar na metáfora rebaixada da "Indecisão no Méier", em que a angústia se dá pela escolha... entre dois cinemas vizinhos: "que tortura lançam no Méier!". Também em "La possession du monde" a "mensagem da Europa", aguardada dos lábios do ilustre visitante Georges Duhamel, converte-se na prosaica solicitação daquele cocasse fruit jaune cobiçado pelo intelectual da França, num quintal brasileiro.

Entre um velho e um novo mundo, entre reminiscências da vivência provinciana e alguma nova ordem decidindo-se na guerra, o poeta busca ser fiel a duas verdades que lutam ingentemente dentro de si mesmo: a da instância lírica e negativa, circular e impotente, em que o remoer-se é também inutilidade e remorso, e a dos apelos de um epos libertador, negação das negações, que a natureza íntima não sabe recolher com a força plena de uma convicção. Significativamente, os poemas do livro seguinte - José, de 1942 - reinstalarão (como uma espécie de intermezzo) no centro das preocupações do poeta a identidade mais estritamente individual, firmada nos traços da memória autobiográfica, na condição solitária e nos dilemas íntimos de um escritor.

ALCIDES VILLAÇA é professor titular de Literatura Brasileira na USP, onde leciona desde 1973. É autor dos livros de poesia Ondas curtas (Cosac Naify, 2014), Viagem de trem (Claro Enigma, 1988) e O tempo e outros remorsos (Ática, 1975). Tem estudos de fôlego sobre as poesias de Ferreira Gullar e Carlos Drummond de Andrade, como Passos de Drummond (Cosac Naify, 2006). 
J. Helena

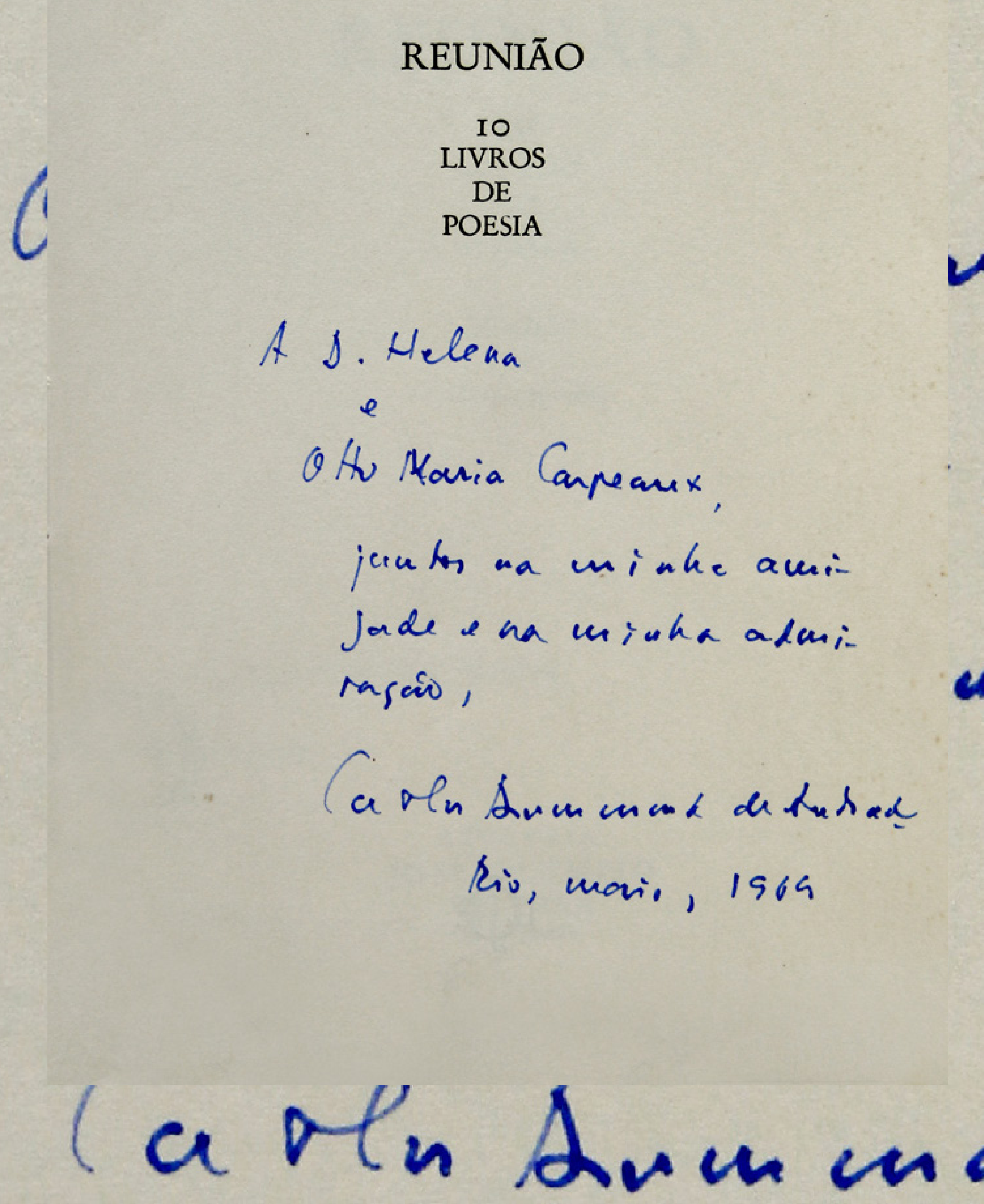


Poesie Texte in zwei Sprachen Herausgegeben von Hans Magnus Enzensberger

A otto Maria Canpeauy,

eme o conovid, afradecid abraso de sen amifo

ams Rnumcudeletuhads

Ris, 28.011 .1965 